\title{
Analysis of Factor Associated with Nutritional Status in Children Under Five Years in Bangka Kenda Village, Manggarai Regency, NTT
}

\author{
Lusia Henny Mariati ${ }^{1}$, Heribertus Handi ${ }^{2}$, Yohana Hepilita ${ }^{3}$ \\ \{lusiahenny87@gmail.com1, herihandi84@gmail.com ${ }^{2}$, yoanhepi@gmail.com ${ }^{3}$ \} \\ Indonesian Catholic University of St. Paul Ruteng, NTT ${ }^{123}$
}

\begin{abstract}
The incidence of malnutrition can increase the risk of morbidity and mortality of children. The purpose of this study was to determine the factors associated with the nutritional status of children under-five years. The research method used is quantitative with cross sectional design. In this study, using the method of Proportionate Stratified Random Sampling, the quantity of respondents was 107 . The instrument used were a questionnaire and weight scales. The analysis data involved using chi-square test and multiple logistic regression. There was a significant association between environmental sanitation $(\mathrm{p}$-value $=0.01, \mathrm{OR}=4,95)$, history of exclusive breastfeeding $(\mathrm{p}$-value $=$ $0.001, \mathrm{OR}=5,84$ ), and a history of infectious disease ( $\mathrm{p}$-value $=0.03, \mathrm{OR}=3,51$ ). There is a need for screening children under five with nutritional problems and improving health on community nutrition.
\end{abstract}

Keywords: nutritional status; exclusive breastfeeding; under-fives years

\section{Introduction}

Nutrition is one of the important factors that determine human health and well-being. The better the nutritional condition of a person, the better his health and well-being. If there is imbalance nutrition, such as a lack of protein-energy and it lasts a long time, it will cause a problem known as a severe lack of protein-energy or malnutrition [1]. The period of the first thousand days of life is a critical period in which the formation and development of important organs occur. If malnutrition occurs at this time, it will have an impact on development and growth in the future [2]. According to data from the nutrition section for health and development of the World Health Organization (WHO), malnutrition is still a global health problem. The data shows that one in ten children are born with low birth weight, in South Asian countries there are one in four children and an average of $45 \%$ of deaths in children under five years are related to malnutrition. These deaths occur in low- and middle-income countries where rates of obesity in children also occur at the same time [3].

Indonesia is one of the countries with the burden of three malnutrition problems that occurred long before the COVID-19 pandemic, namely stunting, underweight and obesity. The challenges in dealing with these three malnutrition problems are likely to worsen due to the COVID-19 Pandemic. Various causes of malnutrition in children under five are direct and indirect causes. The most common direct causes are poor food intake/diet, inadequate breastfeeding practices, nutrition and care for mothers and pregnant women, and high rates of infectious diseases [4]. Indirect causes include insufficient food, inadequate parenting, 
sanitation, clean water/basic health services. In addition, the existence of economic, political, and social crises, including disasters, can also affect the nutritional status of children under five [5]. The decline in the economic status of families due to the COVID-19 pandemic will have an indirect impact on household food security which results in a decrease in the nutritional status of children under five. Furthermore, various efforts to reduce COVID-19 infection can make it difficult to identify and provide essential care and services for children who experience malnutrition [4].

Based on data from Riskesdas Indonesia in 2018, the proportion of malnutrition status decreased by $1.8 \%$ from $5.7 \%$ in 2013 to $3.9 \%$ in 2018 . Meanwhile, malnutrition status in children under five experienced a not too significant decrease, that is only $0.1 \%$ of $13,9 \%$ in 2013 to $13.8 \%$ in 2018. In NTT the proportion of under-nutrition and malnutrition status in children under five as measured by weight for age (BW / U), from 2013 with a total of 33\% experiencing a decrease of $3.5 \%$ to $29.5 \%$ in 2018 . This indicates that the status of undernutrition and malnutrition in NTT has decreased but the incidence is still prominent [6]. According to data from the Manggarai District Health Office in 2018 from January to September the number of children under five in Bangka Kenda village as many as 1109 and 56 children under five with malnutrition status. This case is spread across several auxiliary health centers and village health centers in the working area of the Bangka Kenda Community Health Center. Data on the nutritional status of public health office Manggarai Regency in 2019, there are 1,448 children under five with malnutrition status [7].

Assessment of the nutritional status of children under five can be measured based on anthropometric measurements consisting of variables of age, weight, and height. Age plays an important role in determining nutritional status. The determination error will lead to the wrong interpretation of nutritional status. Body weight is a measure that provides an overview of tissue mass, including body fluids [1]. Bodyweight is a parameter that provides an overview of body mass. Body mass is very sensitive to sudden changes such as infection, decreased appetite, or decreased amount of food consumed. Characteristics of body weight are more representative of a person's current nutritional status [8].

The incidence of undernutrition and malnutrition can increase the risk of morbidity and mortality of children. If malnutrition at the age of under-five continues, it could affect his intellectual performance, work capacity, and health condition at a later age [9]. If the problem of undernutrition at the age of under-five is not resolved, then Indonesia will lose the next generation of quality. The quality of children can be measured through the growth and development of both physical and cognitive. If malnutrition occurs, the impact will be seen, namely disruption of physical development, susceptibility to infectious diseases, and slowing brain development which in turn will have an impact on the low working capacity and intellectual ability of children at the next age. The incidence of undernutrition and malnutrition can be prevented by modifying controllable risk factors, both direct and indirect causative factors such as food intake, infectious diseases, environmental hygiene, economic status, and other risk factors.

This study aims to determine the factors associated with nutritional status in children under five, including the number of family members, parents 'income, sanitation, and clean water, a history of exclusive breastfeeding, a history of infectious diseases in the last one month, parents' knowledge and history of birth weight. 


\section{Method}

This study uses a quantitative research method with a cross sectional approach in order to acknowledge the relationship between the variables, which were observed and measured at the same time [10]. The population in this study were all children under-five at Bangka Kenda Village. The sampling technique used was proportionate stratified random sampling. This sampling technique is used by considering that the member population is not homogeneous and proportionally stratified. The strata in question are the level of parent's education, job, and number of children. Initial sample calculations using the Slovin formula with a degree of error of $5 \%$. Then proceed by counting the members of the sample stratified by proportional random sampling using the proportional allocation formula. The result of the calculation shows that the sample size is 107 respondents.

Data collection was carried out by using a questionnaire consisting of demographic data and factors related to nutritional status, consist of environmental sanitation and clean water, birth weight, parental income, history of exclusive breastfeeding, infectious diseases, and parental knowledge. Meanwhile, to assess body weight using a weight scale. The research instrument was tested for validity and reliability. The collected data have been edited and coded for further processing. Incomplete data were excluded. Data analysis was performed using univariate, bivariate, and multivariate methods. Bivariate analysis was performed using the Chi square test, while multivariate analysis was performed using binary logistic regression.

\section{Result and Discussion}

Table 1 describes the characteristics of children it is known that as many as 27 children were aged 48-60 months, 60 children $(56.1 \%)$ was male, 63 children $(58,9 \%)$ with normal family size according to NKKBS (Happy and Prosperous Small Family Norm), 80 children $(58.9 \%)$ with low parental income, 33 children whose parents work as farmers, 44 children $(41,1 \%)$ with unsanitary environmental sanitation, 77 children $(72 \%)$ did exclusively breastfeed, 63 children $(58,9)$ didn't experience infection in the last month, 61 children $(71 \%)$ with high parental knowledge. Based on nutritional status as many as $75(70,1 \%)$ children were normal nutrition.

Table 1. Distribution Frequency of Characteristics of Children Under Five Years

\begin{tabular}{|c|c|c|c|c|c|}
\hline \multirow{2}{*}{ Variable } & \multirow{2}{*}{ Category } & \multirow{2}{*}{$\begin{array}{l}\text { Frequency } \\
(\mathbf{N})\end{array}$} & \multirow{2}{*}{$\begin{array}{c}\text { Percentage } \\
(\%)\end{array}$} & \multicolumn{2}{|c|}{ Total } \\
\hline & & & & $\mathbf{N}$ & $\%$ \\
\hline \multirow{4}{*}{ Age (months) } & 12 to 23 & 24 & 22,4 & \multirow{4}{*}{107} & \multirow{4}{*}{100} \\
\hline & 24 to 35 & 27 & 25,2 & & \\
\hline & 36 to 47 & 32 & 32 & & \\
\hline & 48 to 60 & 24 & 24 & & \\
\hline \multirow{2}{*}{ Gender } & Male & 60 & 56,1 & \multirow{2}{*}{107} & \multirow{2}{*}{100} \\
\hline & Female & 47 & 43,9 & & \\
\hline \multirow[b]{2}{*}{ Family size } & According to NKKBS & 63 & 58.9 & \multirow{2}{*}{107} & \multirow[b]{2}{*}{100} \\
\hline & $\begin{array}{l}\text { Not according to } \\
\text { NKKBS }\end{array}$ & 44 & 41,1 & & \\
\hline \multirow{3}{*}{ Income } & <regional minimum & 80 & 74,8 & \multirow{3}{*}{107} & \multirow{3}{*}{100} \\
\hline & wage & 27 & 25,2 & & \\
\hline & $\geq$ regional minimum & & & & \\
\hline
\end{tabular}




\begin{tabular}{|c|c|c|c|c|c|}
\hline & wage & & & & \multirow{3}{*}{100} \\
\hline \multirow{2}{*}{ Parent's Job } & Farmer & 89 & 83,3 & \multirow{2}{*}{107} & \\
\hline & Entrepreneur & 41 & 16,8 & & \\
\hline \multirow{2}{*}{ Sanitation and clean water } & Healthy & 44 & 41,1 & \multirow{2}{*}{107} & \multirow{2}{*}{100} \\
\hline & Not healthy & 63 & 58,9 & & \\
\hline \multirow{2}{*}{$\begin{array}{l}\text { History of exclusive } \\
\text { breastfeeding }\end{array}$} & Yes & 77 & 72 & \multirow{2}{*}{107} & \multirow{2}{*}{100} \\
\hline & No & 30 & 28 & & \\
\hline \multirow{2}{*}{ History of infectious disease } & Yes & 44 & 41,1 & \multirow{2}{*}{107} & \multirow{2}{*}{100} \\
\hline & No & 63 & 58,9 & & \\
\hline \multirow{2}{*}{ Parent's knowledge } & High & 61 & 57 & \multirow{2}{*}{107} & \multirow{2}{*}{100} \\
\hline & Low & 46 & 43 & & \\
\hline \multirow{2}{*}{ Birth weight } & Low birth weight & 10 & 9,4 & \multirow{2}{*}{107} & \multirow{2}{*}{100} \\
\hline & Normal birth weight & 97 & 90,6 & & \\
\hline \multirow{2}{*}{$\begin{array}{l}\text { Nutritional status (based on } \\
\text { weight toward age) }\end{array}$} & Normal & 75 & 70,1 & \multirow{2}{*}{107} & \multirow{2}{*}{100} \\
\hline & Under nutrition & 32 & 29,9 & & \\
\hline
\end{tabular}

Based on Table 2, it is known that the results of the bivariate analysis, four variables are significantly related to the nutritional status of children under five, including the number of family members $(\mathrm{p}$-value $=0.038, \mathrm{OR}=2.42)$, sanitation and clean water factors $(\mathrm{p}$-value $=$ $0.000, \mathrm{OR}=8,0)$, the factor of history of exclusive breastfeeding $(\mathrm{p}$-value $=0.000, \mathrm{OR}=8.50)$ and the factor of history of infectious disease ( $\mathrm{p}$-value $=0.001, \mathrm{OR}=5.85$ ).

Table 2. Bivariate Analysis of Nutritional Status Risk Factor of Children Under-Five

\begin{tabular}{|c|c|c|c|c|c|c|c|c|c|}
\hline \multirow{3}{*}{\multicolumn{2}{|c|}{ Variable }} & \multicolumn{4}{|c|}{ Nutritional Status } & \multirow{3}{*}{ P Value } & \multirow{3}{*}{ OR } & \multicolumn{2}{|c|}{$95 \% \mathrm{CI}$} \\
\hline & & \multicolumn{2}{|c|}{ Normal } & \multicolumn{2}{|c|}{ Under nutrition } & & & \multirow{2}{*}{ Min } & \multirow{2}{*}{$\operatorname{Max}$} \\
\hline & & $\mathrm{n}$ & $\%$ & $\mathrm{n}$ & $\%$ & & & & \\
\hline Family size & $\begin{array}{l}\text { According to } \\
\text { NKKBS } \\
\text { Not according to } \\
\text { NKKBS } \\
\end{array}$ & $\begin{array}{l}49 \\
26\end{array}$ & $\begin{array}{c}65 \\
, 3 \\
34,7\end{array}$ & $\begin{array}{l}14 \\
18\end{array}$ & $\begin{array}{l}43,8 \\
56,2\end{array}$ & 0,038 & 2,42 & 1,04 & 5,64 \\
\hline $\begin{array}{l}\text { Parental } \\
\text { income }\end{array}$ & $\begin{array}{l}<\text { regional } \\
\text { minimum wage } \\
\geq \text { regional } \\
\text { minimum wage }\end{array}$ & $\begin{array}{l}57 \\
18\end{array}$ & $\begin{array}{l}76 \\
24\end{array}$ & $\begin{array}{c}23 \\
9\end{array}$ & $\begin{array}{l}71,9 \\
28,1\end{array}$ & 0,653 & 1,24 & 0,49 & 3,16 \\
\hline $\begin{array}{l}\text { Sanitation and } \\
\text { clean water }\end{array}$ & $\begin{array}{l}\text { Healthy } \\
\text { Not healthy }\end{array}$ & $\begin{array}{l}40 \\
35 \\
\end{array}$ & $\begin{array}{l}53,3 \\
46,7 \\
\end{array}$ & $\begin{array}{c}4 \\
28 \\
\end{array}$ & $\begin{array}{l}12,5 \\
87,5 \\
\end{array}$ & ), 000 & 8,00 & 2,55 & 25,05 \\
\hline $\begin{array}{l}\text { History of } \\
\text { exclusive } \\
\text { breastfeeding }\end{array}$ & $\begin{array}{l}\text { Yes } \\
\text { No }\end{array}$ & $\begin{array}{l}64 \\
11\end{array}$ & $\begin{array}{l}85,3 \\
14,7\end{array}$ & $\begin{array}{l}13 \\
19\end{array}$ & $\begin{array}{l}40,6 \\
59,4\end{array}$ & ),000 & 8,50 & 3,29 & 22,04 \\
\hline $\begin{array}{l}\text { History of } \\
\text { infectious } \\
\text { disease } \\
\end{array}$ & $\begin{array}{l}\text { Yes } \\
\text { No }\end{array}$ & $\begin{array}{l}36 \\
39\end{array}$ & $\begin{array}{l}48 \\
52\end{array}$ & $\begin{array}{c}27 \\
5\end{array}$ & $\begin{array}{l}84,4 \\
15,6\end{array}$ & ), 001 & 5,85 & 2,03 & 16,82 \\
\hline $\begin{array}{l}\text { Parent's } \\
\text { knowledge }\end{array}$ & $\begin{array}{l}\text { High } \\
\text { Low }\end{array}$ & $\begin{array}{l}41 \\
34 \\
\end{array}$ & $\begin{array}{l}54,7 \\
45,3 \\
\end{array}$ & $\begin{array}{l}20 \\
12 \\
\end{array}$ & $\begin{array}{l}62,5 \\
37,5 \\
\end{array}$ & ), 545 & 0,72 & 0,31 & 1,69 \\
\hline Birth weight & $\begin{array}{l}\text { Low birth } \\
\text { weight } \\
\text { Normal birth } \\
\text { weight }\end{array}$ & $\begin{array}{c}6 \\
69\end{array}$ & $\begin{array}{c}8 \\
92\end{array}$ & $\begin{array}{c}4 \\
28\end{array}$ & $\begin{array}{l}12,5 \\
87,5\end{array}$ & ),482 & 0,61 & 0,16 & 2,32 \\
\hline
\end{tabular}

Table 3 shows the results of the multivariate analysis of factors related to the nutritional status of children under five which consists of four variables, that is family size, sanitation, 
and clean water, history of exclusive breastfeeding, and history of infectious diseases. The results of binary logistic regression tests showed that the factor most associated with the highest OR value was the history of exclusive breastfeeding with a p-value of 0.001 .

Several factors that affect the nutrition of children under five in this study include the number of family members, family income, birth weight, parental knowledge, history of infectious diseases, and history of breastfeeding. The results of the bivariate analysis showed that four variables had a significant relationship with the nutritional status of children under five, while the other three factors, namely parents 'income, parents' knowledge, and children's birth weight had no significant relationship. The results of the multivariate logistic regression analysis show that factors that have a significant relationship with the nutritional status of children under five include environmental sanitation and clean water, a history of exclusive breastfeeding, and a history of infectious diseases in the last month.

The results showed that the OR value of exclusive breastfeeding on the nutritional status of children under five was 5.84 which means that children with a history of not getting exclusive breastfeeding will be at risk of experiencing under-nutrition 5 times more than those who get exclusive breastfeeding. Exclusive breastfeeding is a staple food that provides benefits for the health of the baby. Breast milk has the nutrients babies need in the first six months of life. Exclusive breastfeeding must be given for six months to achieve optimal growth, development, and health. Breast milk protects the body against infectious diseases such as diarrhea, pneumonia, and other respiratory infections and provides long-term protection for the health of children [11].

Infants who were exclusively breastfed for six months and continued for one life had a lower risk of developing infectious diseases than those who received formula milk. Data from the Indonesian Pediatrician Association (IDAI) shows that breastfeeding can prevent $1 / 3$ of the incidence of upper respiratory tract infections (ISPA), a 50\% reduction in the incidence of diarrhea and severe intestinal disease by $58 \%$ [12]. This research is in line with research conducted by Novela and Kartika, where one of the factors that affect malnutrition in children under five in Bukit Tinggi is the history of exclusive breastfeeding with a p-value of 0.021 , $\mathrm{OR}=7$ [13].

Research by Ibrahim, et al shows that there is a significant relationship between the practice, frequency, and duration of exclusive breastfeeding and malnutrition [14]. The prevalence of malnourished children in the group that did not receive exclusive breastfeeding was $41.5 \%$ for underweight, $24.4 \%$ for acute malnutrition, and $47.5 \%$ for chronic malnutrition. Poor breastfeeding may be contributing to a higher risk of malnutrition among the under five children. The results of interviews conducted by researchers with mothers who did not provide exclusive breastfeeding showed that the constraints of exclusive breastfeeding were mainly due to the mother's lack of understanding of the adequacy of breastfeeding, especially in the first week of breastfeeding and insufficient milk production due to lack of care during pregnancy.

The results also showed that the historical factor of infectious disease had a significant relationship with the OR value of 3.51, which means that children under five who had a history of infectious diseases had a 3.5 times risk of experiencing underweight malnutrition. Infection can cause a child to lose his appetite. This disease also consumes several protein and calories that should be used for the growth [15].

The types of infectious diseases experienced by children under five in Bangka Kenda Village are upper respiratory tract infections and diarrhea. Inadequate nutritional intake during illness can cause undernutrition and malnutrition. Nutritional adequacy and infectious diseases are closely related. If you lack nutrition, the body will easily experience infection due to 
decreased immunity. Conversely, if the body experiences recurrent infections, the nutritional needs increase, but due to disease, the child's body experiences a decrease in appetite, causing malnutrition. Certain health conditions such as tuberculosis (TB), diarrhea, measles, etc., can exacerbate malnutrition in children, and a combination of these health problems can weaken the immune system [9].

This research is in line with research conducted by Oktavia; Masnah, where there is a significant relationship in the results of the bivariate test for infectious diseases with malnutrition status in children under five with p-value <0.005 [16], [17]. Based on the researcher's analysis, several factors can influence the incidence of infection in children under five, including the status of exclusive breastfeeding, environmental sanitation conditions related to unavailability of household sewerage, the availability of clean water where some people still draw water from rivers. Environmental sanitation factors, the number of family members in one house is a factor in causing infection in children [18].

The next factors related to the nutritional status of children under five are environmental sanitation and clean water. The results showed that environmental sanitation factors and water sources had a significant relationship with the OR value of 4.95 , which means that homes with unhealthy environmental sanitation had a 4.95 times risk of causing undernutrition in children under five. Children under two years of age who live in an unclean household environment are at risk of experiencing underweight compared to those living in a clean household environment [19].

Other factors found that influence malnutrition includes a lack of access to basic sanitation, lack of resources, and lack of hand-washing facilities, thus illustrating poor sanitation practices that can cause disease and affect the nutritional status of toddlers [8]. This research is in line with the research conducted by Tekile, et al, where there is a significant relationship between household wealth index, water, and toilet facility with underweight in Ethiopia with $\mathrm{p}$ $<0.005$ [18]. The results of observations carried out by the researchers showed that the lack of cleanliness of the latrines, lack of water sources, household sewage, cleanliness of the house which is still low are the trigger factors for infectious diseases that have an impact on malnutrition.

Another factor that can affect the nutritional status of children under five is the number of household members. The results showed that in the bivariate test, there was a significant relationship between the number of household members and the nutritional status of children under five with $\mathrm{p}$-value $=0.038, \mathrm{OR}=2.42$. Whereas in the logistic regression multivariate test the number of household members was not significantly related to the nutritional status, $\mathrm{p}$ value $=0.10$ and $\mathrm{OR}=2.37$. The positive value coefficient and the $\mathrm{OR}$ value of 2.37 shows that the number of household members has 2 times higher risk of causing malnutrition in children under five compared to the number of household members who are not dense. The number of household members is a factor that influences the nutritional status of children under five. It can be related to parents' income, environmental sanitation [20].

The results showed that most of the parents of children under five in the village of Bangka Kenda worked as farmers with a lower income than the regional minimum wage in Manggarai district. This can be one of the factors that can lead to a lack of availability of food that is complete with nutritional composition, including protein, fat, carbohydrates, and vitamins. In addition, sanitation factors also play a role in influencing the health of the members of the house. From the results of interviews by researchers, it is known that there are household members who have a smoking habit. Cigarette smoke is known to cause respiratory tract infections in children. 
A large number of family members and the smoking habit of household members trigger the occurrence of infectious diseases in family members which can ultimately have an impact on the nutritional status of children under five. This study is in line with research conducted by Ghimire, et al with the results of logistic regression analysis showing, households with a family size of five or more members were significantly associated with severe acute malnutrition with (AOR): 3.96; 95\%. CI: 1.23-12.71) [21]. Research by Tekile, et al, shows that there is a significant relationship between family size and underweight under five with a $\mathrm{p}$-value $=0.001[18]$

The results showed that there were three factors, namely parents' income, history of childbirth weight, and parental knowledge which were not significantly related to the nutritional status of children under five. The results of the analysis showed that the income factor did not affect the malnutrition status of children under five in Bangka Kenda village because of the support for the availability of staple foods such as rice and vegetables which were always available at home. Therefore, even though the amount of income is low, the availability of staple food rice and vegetables is always fulfilled. It is known that the majority of parents of children under five in Bangka Kenda Village are farmers.

The history of birth weight of children under five is one of the factors that can affect the nutritional status of children under five. The results showed that weight history had no significant effect on the nutritional status of children under five. The insignificant relationship can be seen from the results which show a p-value $>0.482$. The history factor of a child's birth weight is not significantly related to nutritional status, can be influenced by the support of adequate nutritional intake during the development of children under five.

The next factor is parental knowledge which is one of the factors that can affect the nutritional status of toddlers. Knowledge can support the successful growth and development of toddlers where with this knowledge parents try to provide everything related to the nutritional needs of toddlers. However, in this study, it was found that there was no relationship between parental knowledge and the nutritional status of children under five in Bangka Kenda Village. Although in the results of the study it was found that there were parents with low knowledge who had malnourished children. This research is in line with research conducted by Raji, et al which shows that there is no significant relationship between knowledge factors and malnutrition among children under five in Nigeria [22].

\section{Conclusion}

The incidence of malnutrition in children under five in Bangka Kenda Village, Wae Ri'is District, Manggarai Regency is still quite high. The factors most related to the nutritional status of children under five in Bangka Kenda Village are a history of exclusive breastfeeding, infectious diseases, environmental sanitation, and clean water, and the number of family members. The influence of these factors can be used as a reference for developing strategies to reduce the incidence of malnutrition during pandemic COVID-19. There needs to be strong support from the government to improve the quality standards of the health of children under five by facilitating hygiene facilities and health education so that children are healthy and free from malnutrition. There is a need for screening children under five with nutritional problems and improving health on community nutrition.

This research is limited to only analyzing indirect factors that can affect the nutritional status of children under five. The parameters used to assess nutritional status are only based on 
body weight for the age of children under five. It is hoped that further research can combine several parameters of nutritional status to get an accurate comparison related to the nutritional status of children under five.

\section{References}

[1] M. Septikasari, Majestika S.ST., Status Gizi Anak dan Faktor yang Mempengaruhi, 1st ed. Yogyakarta: UNY Press, 2018.

[1] A. J. L. A. da Cunha, Á. J. M. Leite, and I. S. de Almeida, "The Pediatrician's Role in the First Thousand Days of the Child: The Pursuit of Healthy Nutrition and Development," J. Pediatr. (Versão em Port., vol. 91, no. 6, 2015, doi: 10.1016/j.jpedp.2015.09.005.

[2] WHO, "Malnutrition is A World Helath Crisis.," 2019. https://www.who.int/nutrition/topics/worldfood-day-2019-malnutrition-world-health-crisis/en/. (accessed Nov. 20, 2020).

[3] UNICEF, "COVID-19 dan Anak-Anak di Indonesia," 2020 https://www.unicef.org/indonesia/sites/unicef.org.indonesia/files/2020-05/COVID-19-dan-Anakanak-di-Indonesia-2020_1.pdf (accessed Nov. 20, 2020).

[4] L. C. Chikhungu, N. J. Madise, and S. S. Padmadas, "How important are community characteristics in influencing children's nutritional status? Evidence from Malawi population-based household and community surveys," Heal. Place, vol. 30, 2014, doi: 10.1016/j.healthplace.2014.09.006.

[5] Riskesdas, "Riset Kesehatan Dasar 2018," 2018. [Online]. Available: https://www.who.int/nutrition/topics/world-food-day-2019-malnutrition-world-health-crisis/en/.

[6] www.nttprov.go.id, "Kesehatan," 2019. http://nttprov.go.id/2018/index.php/kondisiumum/kesehatan (accessed Nov. 20, 2020).

[7] E. Simon Peter, S. Haruna Aliyu, and R. Salisu Hassan, "Nutrition Assessment and Factors Influencing Malnutrition among Children under Five in Adjumani District Uganda," J. Adv. Med. Med. Res., 2019, doi: 10.9734/jammr/2019/v29i330074.

[8] R. E. Kalu and K. D. Etim, "Factors Associated with Malnutrition Among Underfive Children In Developing Countries: A review," Glob. J. Pure Appl. Sci., vol. 24, no. 1, 2018, doi: 10.4314/gjpas.v24i1.8.

[9] S. Notoatmodjo, Metodologi penelitian kesehatan. PT. Rineka Cipta, 2012.

[10] WHO, "Breastfeeding," 2020. https://www.who.int/health-topics/breastfeeding\#tab=tab_1.

[11] IDAI, "Dampak dari Tidak Menyusui di Indonesia," 2016. https://www.idai.or.id/artikel/klinik/asi/dampak-dari-tidak-menyusui-di-indonesia.

[12] V. Novela and L. Kartika, "Faktor-Faktor Status Gizi Kurang Pada Anak Usia Prasekolah di Wilayah Kerja Puskesmas Guguk Panjang Kota Bukittinggi," J. Endur., vol. 4, no. 2, 2019, doi: 10.22216/jen.v4i2.4021.

[13] A. Ibrahim, M. Alsiek, M. Ngoma, and Adam, "Breastfeeding among Infants and Its Association with the Nutritional Status of Children Under Five Yearsin Khartoum Sudan,” Int. J. Heal. Care Sci., vol. 3, no. 1, pp. 177-184, 2015, [Online]. Available: www.researchpublish.com.

[14] A. Sholikah, E. Rustiana, and A. Yuniastuti, "Faktor - Faktor yang Berhubungan dengan Status Gizi Balita di Pedesaan dan Perkotaan," Public Heal. Perspect. J., vol. 2, no. 1, 2017, [Online]. Available: http://journal.unnes.ac.id/sju/index.php/phpj.

[15] S. Oktavia, L. Widajanti, and R. Aruben, "Faktor-Faktor yang Berhubungan dengan Status Gizi Buruk pada Balita Di Kota Semarang Tahun 2017 (Studi Di Rumah Pemulihan Gizi Banyumanik Kota Semarang)," J. Kesehat. Masy., vol. 5, no. 3, 2017.

[16] C. Masnah and I. M. Saputri, "Faktor risiko gizi kurang pada balita di Puskesmas Paal V Kota Jambi," Ris. Inf. Kesehat., vol. 9, no. 2, 2020, doi: 10.30644/rik.v9i2.451.

[17] A. K. Tekile, A. A. Woya, and G. W. Basha, "Prevalence of malnutrition and associated factors among under-five children in Ethiopia: Evidence from the 2016 Ethiopia Demographic and Health Survey," BMC Res. Notes, vol. 12, no. 1, 2019, doi: 10.1186/s13104-019-4444-4. 
[18] N. Rahman, M. R. Napirah, D. Nadila, and Bohari, "Determinants of stunting among children in urban families in palu, Indonesia," Pakistan J. Nutr., vol. 16, no. 10, 2017, doi: 10.3923/pjn.2017.750.756.

[19] G. N. Khan et al., "Prevalence and associated factors of malnutrition among children under-five years in Sindh, Pakistan: A cross-sectional study," BMC Nutr., vol. 2, no. 1, 2016, doi: 10.1186/s40795-016-0112-4.

[20] U. Ghimire, B. K. Aryal, A. K. Gupta, and S. Sapkota, "Severe acute malnutrition and its associated factors among children under-five years: A facility-based cross-sectional study," BMC Pediatr., vol. 20, no. 1, 2020, doi: 10.1186/s12887-020-02154-1.

[21] I. A. Raji et al., "Knowledge of Factors Contributing to Child Malnutrition among Mothers of Under-five Children in Sokoto Metropolis, North-West Nigeria," J. Community Med. Prim. Heal. Care, vol. 32, no. 2, 2020, doi: 10.4314/jcmphc.v32i2.2 